was offered by the great ball he gave in Government House, Calcutta, on 6th January, 1903, the exact centenary of Lord Wellesley's ball, where all the guests appeared in costumes of the period, and Lord Curzon himself wore the uniform of Lord Wellesley.

Lord Curzon's name will be ever gratefully remembered by all students of Indian history and archæology, and the many labours of love he undertook in the midst of his strenuous official life will bear permanent testimony to his devotion to the records of India's great past.

F. Denison Ross.

\title{
Bishop Casartelli
}

By the death of the Right Rev. Louis Charles Casartelli, Roman Catholic Bishop of Salford, a distinguished name is removed from the roll of Members of this Society, and Oriental learning, and Iranian studies in particular, sustain the loss of an eminent and accomplished scholar. Dr. Casartelli was of Italian descent, his father being a refugee from Como in Lombardy ; and his son spoke and wrote with some pride of his Lombard origin as forming a closer link between himself and the people of the land of his adoption.

As a boy he was educated at Salford Grammar School, whence in due time he proceeded to Ushaw College, associated with the University of London, and, at the close of a brilliant course, graduated Master of Arts at the University with a gold medal for Classics.

By this time the ancient University of Louvain had been revived, and there, for two periods, with eight years' interval, Casartelli studied Avestan, Pehlavi, and Sanskrit, under the illustrious Professor de Harlez. The firstfruit of these studies was his excellent treatise entitled La Philosophie religieuse du Mazdéisme sous les Sassanides, a work that still remains the most valuable and authoritative monograph on the Mazdeism of the Sasanian period, and which at once placed its author amongst the foremost Iranists of his day. For this he 
deservedly received the degree of Doctor of Letters from the University of Louvain. An English translation of that work, done by a Parsi scholar in 1889, was dedicated to the President of this Society, the late Lord Reay. Another work of great value belonging to the same period was his Traité de Médecine Mazdéenne. Moreover, in addition to many articles contributed to various Festschriften and learned Journals, Dr. Casartelli wrote, during his ripest years, to Hastings' Encyclopcedia of Religion and Ethics on the Iranian aspect of the following important subjects:-Celibacy, Charms and Amulets, Disease and Medicine, Dualism, King, Iaw, Philosophy, Saints and Martyrs, Salvation, Sasanians, Sin, Soul, State of the Dead.

With profound scholarship and wide knowledge he combined sound judgment, and his opinion on difficult matters relating to the religion and culture of ancient Iran was eagerly sought and reluctantly departed from by his fellow Iranists in the East and the West. His remarkable versatility is shown by the fact that notwithstanding the onerous duties of his high ecclesiastical office and his lectureship in Iranian languages in Manchester University, he also held, in connexion with that city, the presidencies of the Statistical Society and of the Egyptian Association, and had a seat on the Council of the Geographical Society. Bishop Casartelli identified himself closely with the civic life of Manchester, and was highly esteemed by people of all religious communions. He became a member of the Royal Asiatic Society in 1889, and in 1919 his name was placed on the roll of Honorary Members.

E. EDWARDS. 